See discussions, stats, and author profiles for this publication at: https://www.researchgate.net/publication/335477658

\title{
Making olive oil sustainable
}

Article in Science · August 2019

DOI: 10.1126/science.aay 7899

CITATIONS

7

3 authors:

8

Francisco Moreira

University of Porto

297 PUBLICATIONS 8,069 CITATIONS

SEE PROFILE

(E)

Pedro Beja

University of Porto

339 PUBLICATIONS 6,341 CITATIONS

SEE PROFILE

Some of the authors of this publication are also working on these related projects:

Project PROT OVT View project

Project Farmland ecology View project
Herrera, J. M.

Mediterranean Institute for Agriculture Environment and Development 45 PUBLICATIONS 676 CITATIONS

SEE PROFILE 
estimated at 21 years (2). This slow pace and ever-increasing backlog are the result of the decreasing number of taxonomists and the lack of financial investment in the field of taxonomy and museum collections (3). Many megadiverse groups, including less charismatic plants, fungi, and invertebrates, have very few or no specialists with the necessary knowledge to describe them, whereas most scientists study charismatic groups and dedicate their time to ecological and evolutionary science (4). Without support for proper long-term housing and morphological descriptions, which is what is required to officially name a species under the rules of the International Codes of Nomenclature (5), species identified by DNA barcode will likely just add to the already massive backlog.

The lack of investment in natural history collections and research worldwide is clear and especially apparent in developing countries (6) that hold most of the biodiversity on our planet. Many new species that might be at risk of extinction in nature have the same risk of disappearing from museum shelves due to the lack of maintenance (6). DNA barcodes alone are not enough to document the biological diversity. Overcoming the taxonomic backlog can lead to incredible advances in conservation and biodiversity science, but this will only happen if governments, societies, and institutions recognize and invest in taxonomists, museum collections, and their staff.

H. T. Pinheiro' , C. S. Moreau ${ }^{2}$, M. Daly ${ }^{3}$, L. A. Rocha ${ }^{1 *}$

${ }^{1}$ California Academy of Sciences, San Francisco, CA 94118, USA. ${ }^{2}$ Cornell University, Ithaca, NY 14853, USA. ${ }^{3}$ Ohio State University, Columbus, $\mathrm{OH}$ 43212, USA.

*Corresponding author

Email: Irocha@calacademy.org

\section{REFERENCES AND NOTES}

1. Q.D.Wheeler, P. H. Raven, E. O. Wilson, Science 303 285 (2004).

2. B. Fontaine, A. Perrard, P. Bouchet, Curr. Biol. 22 , R943 (2012).

3. M. C. Ebach, A. G. Valdecasas, Q. D. Wheeler, Cladistics 27, 550 (2011).

4. L. W. Drew, BioScience 61, 942 (2011).

5. International Commission on Zoological Nomenclature, International code of Zoological Nomenclature. Fourth Edition (The International Trust for Zoological Nomenclature, London, UK, 1999)

6. K.A.Zamudio et al., Science 361,1322 (2018).

10.1126/science.aay7174

\section{Trophy hunting bans imperil biodiversity}

Trophy hunting is under pressure: There are high-profile campaigns to ban it, and several governments have legislated against it (1). In the United States, the CECIL Act (2) would prohibit lion and elephant trophy imports from Tanzania, Zambia, and Zimbabwe and restrict imports of species listed as threatened or endangered on the Endangered Species Act. Australia, the Netherlands, and France have also restricted trophy imports (1), and the United Kingdom is under pressure to follow. Calls for hunting bans usually cite conservation concerns. However, there is compelling evidence that banning trophy hunting would negatively affect conservation.

In African trophy hunting countries, more land has been conserved under trophy hunting than under national parks (3), and ending trophy hunting risks land conversion and biodiversity loss (4). Poorly managed trophy hunting can cause local population declines (5), but unless better land-use alter-

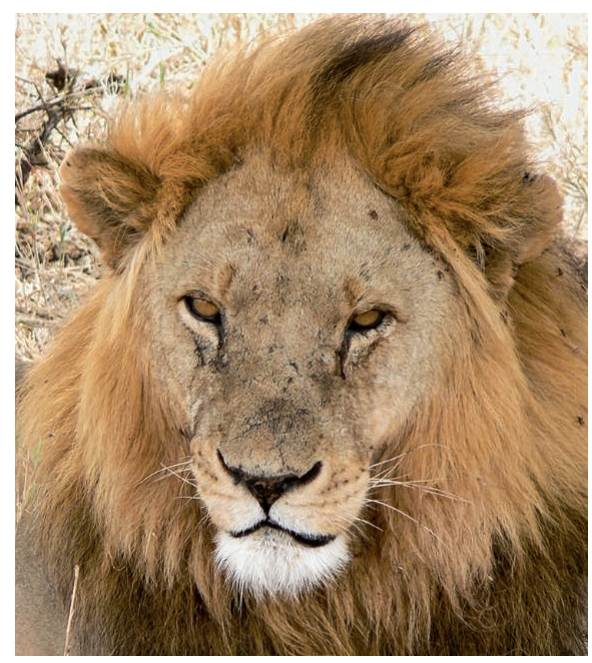

Banning trophy hunting can have unintended consequences for species such as lions.

natives exist, hunting reforms-which have proved effective (6)-should be prioritized over bans (7). Positive population impacts of well-regulated hunting have been demonstrated for many species, including rhinos, markhor, argali, bighorn sheep, and many African ungulates (7).

Trophy hunting can also provide income for marginalized and impoverished rural communities (7). Viable alternatives are often lacking; opponents of hunting promote the substitution of photo-tourism, but many hunting areas are too remote or unappealing to attract sufficient visitors (8). Species such as lions fare worst in areas without photo-tourism or trophy hunting (9), where unregulated killing can be far more prevalent than in hunting zones, with serious repercussions for conservation and animal welfare (10). Focusing on trophy hunting also distracts attention from the major threats to wildlife.

The International Union for Conservation of Nature (IUCN), a global conservation authority, clearly concludes that "with effective governance and management trophy hunting can and does have positive impacts" on conservation and local livelihoods (7). Although there is considerable room for improvement, including in governance, management, and transparency of funding flows and community benefits (11), the IUCN calls for multiple steps to be taken before decisions are made that restrict or end trophy hunting programs (7). Crucially, as African countries call for a "New Deal" for rural communities (12) that allows them to achieve the self-determination to sustainably manage wildlife and reduce poverty, it is incumbent on the international community not to undermine that. Some people find trophy hunting repugnant (including many of us), but conservation policy that is not based on science threatens habitat and biodiversity and risks disempowering and impoverishing rural communities.

Amy Dickman', ${ }^{1,2}$ Rosie Cooney ${ }^{2,3}$, Paul J. Johnson"*, Maxi Pia Louis ${ }^{4}$, Dilys Roe ${ }^{2,5}$, and 128 signatories

'Wildlife Conservation Research Unit, Department of Zoology, University of Oxford, The RecanatiKaplan Centre, Tubney, Oxfordshire, OX13 5QL, UK. ${ }^{2}$ IUCN SSC Sustainable Use and Livelihoods Specialist Group, 1196, Gland, Switzerland. ${ }^{3}$ Fenner School of Environment and Society, Australian National University, 0200 ACT, Australia. ${ }^{4}$ Namibian Association of CBNRM Support Organisations, Windhoek, Namibia. ${ }^{5}$ Natural Resources Group, International Institute for Environment and

Development, London WC1X 8NH, UK.

*Corresponding author.

Email: paul.johnson@zoo.ox.ac.uk

\section{REFERENCES AND NOTES}

1. E.Ares, "Trophy hunting," House of Commons Library Briefing Paper Number 7908 (2019); https://researchbriefings. parliament.uk/ResearchBriefing/Summary/CBP-7908.

2. U.S. Congress, H.R.2245-CECILAct (2019); www.congress. gov/bill/116th-congress/house-bill/2245/text.

3. P.A.Lindsey, P.A. Roulet, S. S. Romanach, Biol. Conserv. 134, 455(2007).

4. E. Di Minin etal., Conserv. Biol. 27,808(2013)

5. C. Packer etal., Conserv. Biol. 25,142 (2011).

6. C.M.Begg, J.R. B. Miller, K. S. Begg, J.Appl. Ecol. 55 139 (2018).

7. IUCN, "Informing decisions on trophy hunting" (IUCN, Gland, Switzerland, 2016)

8. C.W.Winterbach, C. Whitesell, M. J.Somers, PLOS One 10 , e0135595(2015).

9. P.A.Lindsey etal., Biol. Conserv. 209,137 (2017)

10. A.J. Dickman, in Conflicts in Conservation: Navigating Towards Solutions, S. M. Redpath, R. J. Gutierrez, K. A. Wood, J.C. Young, Eds. (Cambridge University Press, Cambridge, 2015), pp.30-32.

11. IUCN SSC,"Guiding principles on trophy hunting as a tool for conservation incentives v 1.0 "(IUCN SSC, Gland, Switzerland, 2012)

12. SouthernAfrica Trust," Declaration-Voices of the communities: Anew deal for rural communities and wild life and natural resources" (2019); www.southernafricatrust.org/2019/06/25/ declaration-voices-of-the-communities-a-new-deal-forrural-communities-and-wildlife-and-natural-resources/.

SUPPLEMENTARY MATERIAL

science.sciencemag.org/content/365/6456/874/suppl/DC1 List of Signatories

10.1126/science.aaz0735 


\section{Science}

\section{Making olive oil sustainable}

Francisco Moreira, José M. Herrera and Pedro Beja

Science 365 (6456), 873.

DOI: $10.1126 /$ science.aay7899

ARTICLE TOOLS

REFERENCES

PERMISSIONS http://science.sciencemag.org/content/365/6456/873.1

This article cites 7 articles, 2 of which you can access for free http://science.sciencemag.org/content/365/6456/873.1\#BIBL

http://www.sciencemag.org/help/reprints-and-permissions

Science (print ISSN 0036-8075; online ISSN 1095-9203) is published by the American Association for the Advancement of Science, 1200 New York Avenue NW, Washington, DC 20005. 2017 () The Authors, some rights reserved; exclusive licensee American Association for the Advancement of Science. No claim to original U.S. Government Works. The title Science is a registered trademark of AAAS. 